Article

\title{
Fair Play in Physical Education and Beyond
}

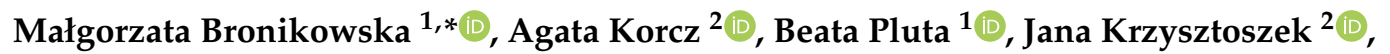

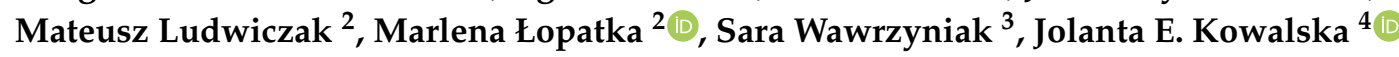 \\ and Michał Bronikowski ${ }^{2} \mathbb{D}$ \\ 1 Department of Recreation, Poznan University of Physical Education, 61-871 Poznań, Poland; \\ bpluta@awf.poznan.pl \\ 2 Department of Didactics of Physical Activity, Poznan University of Physical Education, \\ 61-871 Poznań, Poland; korcz@awf.poznan.pl (A.K.); krzysztoszek@awf.poznan.pl (J.K.); \\ mateusz192@o2.pl (M.L.); wyskok@awf.poznan.pl (M.Ł.); bronikowski@awf.poznan.pl (M.B.) \\ 3 Department of Team Sports Games, University School of Physical Education in Wroclaw, \\ 51-612 Wrocław, Poland; sara.wawrzyniak@awf.wroc.pl \\ 4 Faculty of Educational Sciences, The Department of Physical and Health Education, University of Lodz, \\ 90-137 Łódź, Poland; jolanta.kowalska@uni.lodz.pl \\ * Correspondence: bronikowska@awf.poznan.pl or wadera43@gmail.com; Tel.: +48-835-5422
}

Received: 12 November 2019; Accepted: 6 December 2019; Published: 10 December 2019

\begin{abstract}
The aim of this study is to examine the level of understanding of the principle of fair play by secondary school pupils $(\mathrm{n}=827)$ from the Polish province of Wielkopolska, physical education (PE) students from Poznan University of Physical Education $(n=437)$, and PE teachers $(n=130)$. Two structured survey questionnaires were used, namely: The three-level scale known as the Fair Play Moral Dimensions Concept Scale and a Factors of Moral Influence Scale. There were observed differences between male and female students in their comprehension of the principle of fair play regarding the category of sporting activity practiced. The female teachers' amateur training group more frequently identified the highest level of fair play (32.1\% of the examined female teachers) in comparison with their male colleagues. Moreover, differences were noted between boys and girls at the secondary school level. Boys rated the influence of PE teachers and coaches higher, while girls declared that they were more influenced by media and education. For both boys and girls, parents constituted the highest-rated factor of the influence on their moral development. Students also indicated the influence of parents as the highest-rated factor. Among PE teachers, school, as a source of influence on one's moral development, was awarded higher rates by female than by male teachers. It was observed that parents constituted the highest-rated factor of influence for PE teachers.
\end{abstract}

Keywords: fair play; physical education; moral development; sporting ethics

\section{Introduction}

Since ancient times and through the ages, a crucial part of all attempts to organize sporting life along the concept of the ancient Olympic Games has been focusing attention on competitive ethics (from the Greek 'ethikos'), which today has come to be identified with the British concept of fair play [1]. Although the founders of the ancient games then were not familiar with the concept of fair play, they required athletes taking part in the Greek games to follow generally accepted ethical norms (in Greek, 'kalos kagathos' and 'arete'). Among various historical sources and in information concerning the concept which today we define by the term 'fair play', we may find certain common elements characteristic of the ancient Greek term 'arete', symbolizing a quest for clarity and honesty which simultaneously signified a person's perfection and good character [2-4]. An important factor influencing the later concept of fair play in the British Isles was the earlier Celtic culture, in which the 
rule of 'behavior' ('fir fér') was in force [5]. The noble ideal and that of conducting a fair fight was gradually taken on by the Anglo-Saxons following their conquest of Britain in the Early Middle Ages. The meaning of this concept was later transferred to the term 'fair play' in sporting competitions, a concept which was accepted in continental Europe from the late 18th century, having previously been accepted in English-speaking countries. The idea of British fair play from the 19th century onwards, which one could find in the British public school system (with an emphasis on sports and rules such as rugby, cricket, and boxing, the latter governed by the 'Queensbury rules'), was eventually recognized as a fundamental principle of the modern Olympic Games [1]. Although it is true to say that the idea may sound quite British, it is based on generally accepted ethical norms (so-called universal values), and there are clearly compatible concepts elsewhere in the world, albeit less recognized as of yet, labeled accordingly as local cultural or religious norms.

Almost all behavior with regards to the theme of sports is regulated by ethical codes that must be followed by athletes and sportspersons in general. Therefore, the will to win may exceed the limits of what is permitted in fair play and can lead to poor ethical practices among athletes [2]. In modern sport, the main regulators of behavior aimed at achieving individual and team goals are the rules of the game. This is the lowest (technical) level of regulation of mutual interpersonal relations in a sporting competition. Unfortunately, despite clear (codified) rules of the game and an expectation that these will be accepted by the competing sides as a basis for entering a given competition, their conscious violation is an all-too-often-observed phenomenon in today's world (e.g., fixing results before the game, consciously breaking the rules during the game, as well as the taking back of medals, the nullifying of records, results, and the imposition of punishments, etc. after the game) [6,7]. Just to give a few of the most recent examples: The case of Lance Armstrong's confession of using pharmacological doping in most of his Tour de France victories [8], Steve Smith's suspension from international cricket for ball-tampering - which was a clear violation of the rules of the game and of those concerning sportsmanship [9]—or the threatened exclusion of the entire Russian athletics team from the Olympic Games by WADA (the World Anti-Doping Agency) for manipulation concerning internationally accepted ethics and sport rules at the governmental level [10]. Thus, the evidence indicates that participation in sports does not fulfill its function in the transmission of positive values (such as fair play and sportsmanship). On the contrary, antisocial behaviors (cheating, gamesmanship, doping) violating the rules or the spirit of the game have become a part of the game [11], with athletes using various forms of moral disengagement to differentiate between deception and 'clever' play, or which can lead to other unwanted antisocial behaviors in school, such as bullying or cheating (as well as beyond the school gym in examples of plagiarism or exam cheating).

Thus, behaviors as defined by the term 'fair play' must be something more than just following the regulations outlined by the rules of the game. They involve additionally following unwritten rules governing a given sport discipline, as well as presenting this behavior in a wider dimension in life outside sport [12]. Here one may pose a question, and indeed voice a concern, as to what extent physical education (PE) in school plays a role in the overall sound development of a young person that goes beyond the school gym. In most PE curricula, the sustainability of the subject is associated with the development of health-related behaviors and attitudes for maintaining an active lifestyle throughout one's life. However, the question remains as to whether moral development is equally stressed in PE teaching, given that this should also be a life-long learning outcome.

Nowadays, the education of children is very much focused on sustainable development, which has become a key issue for the educational system as a whole. This idea is based primarily on meeting the needs of the present without compromising the ability of future generations to meet their own needs [13]. Currently, it is highly important to be able to act sustainably to change recent patterns of action by making value judgements about different ways to act. One of the examples of sustainable living might concern the health of human populations in the long-term perspective [14-17], also in terms of sound personal development, including both physical and moral virtues. 
Today, fair play is the main principle of sports ethics. It outlines the course of competition according to strictly defined rules which may exist in two ways. The first of these is formal-through a top-down external order prohibiting winning in a dishonest or improper manner, since this is a radical contradiction of the concept of fairness [18]. The second is informal-much more important, but also more difficult to implement; it is one in which a huge role is played by the participant's individual level of moral competence, based on a formulated (or unformulated) system of values, determining their behavior in a real-life situation.

There are many terms referring to human morality, very often going beyond the boundaries of sporting competitiveness or the concept of fair play. Young people define their understanding of morality through the content of expressed judgments and assessments, and then on behavior in accordance with moral rules or principles which are natural for their cultural codes and considered to be fundamental or universal in their social and environmental contexts. However, moral development does not always go hand in hand with moral progress. Krawczyk [19] actually perceives fair play as a potential value which every person possesses if they are only willing and able to act in accordance with an ethical code, but not as something that is given or taken for granted.

A valuable tool aiding the introduction of children and teenagers to the world of values turns out to be an Olympic education which, along with the principle of fair play, makes it possible to merge with trends concerning modern theories of education [20,21]. As part of alternative education, it may appear as an integral part of teaching programs at various stages of schooling, proving its educational effectiveness [22,23]. Research on the effectiveness of the moral program based on Olympism contained in the Fair Play for Kids program introduced by Gibbons et al. in Canada shows that 'moral development is not automatically derived from participating in physical education (PE) classes, and specially prepared teaching programs with regard to issues concerning moral development may supplement the development process' [24] (p. 253). In an intervention program on prosocial attitudes and behaviors of coaches and adolescent players, Cruz et al. [25] pointed to the quality of adult (sport coach) leadership as a crucial factor in the development and promotion of sportsmanship and fair play. Similar findings are reported by Garcia-Mas et al. [26], who found that a psychoeducational program for sport coaches based on the concept of positive training promotes attitudes of change and stimulates the personal and social development of coaches, endorsing their own competences towards promoting fair play and fighting against violence and discrimination among players. Hodge and Lonsdale [27] found that sport coaches who tend to supervise athletes in a very controlled way elicit a higher level of moral disengagement, increasing antisocial behaviors towards their opponents as well as teammates, while a supportive coaching style is more effective in developing contrary behaviors. Moreover, in their study, Shu, Gino, and Bezerman [28] found that moral disengagement mediates the relationship between cheating and forgetting moral rules. Moreover, Mallia et al. [29] pointed to the roles of task and ego orientation as predictors of moral disengagement and antisocial attitudes in young athletes.

By promoting the values of fair play wisely, it is possible to support the moral development and social upbringing of children. It may help in facilitating getting to know the world and oneself, especially since these values are well understood and appreciated by children and teenagers, and are highly placed in the hierarchy of moral values [30]. Particular attention should be focused here on the social perception of the principles of fair play in sport and life in all its aspects [31]. In this regard, the philosophy of Olympism, which aspires to promote virtuous behaviors in order to contribute to building a more peaceful and better world through the ethical practice of PE and sport, has a useful legitimacy. Fostering education that focuses on Olympism would need to adopt a pedagogy that is emancipatory in nature and socially transformative in action if it is to be effective. Although the adoption of a critical thinking via Olympic education and through a PE setting is a complex arrangement, it sometimes does not have the capacity to facilitate the confrontation of moral dilemmas within a legitimate learning context $[32,33]$. 
Unfortunately, sport today is undergoing a crisis of values. With fouling now so fashionable, in the last twenty years, vicious and rule-breaking behavior has become something not just visible and tolerated, but in fact, something to be shown off [34]. Thus, that which is attractive, spectacular, and easy is destroying sport, while being honest and playing by the rules of the game has recently become neither simple nor easy, especially since the stakes of victory mean not only glory and medals but also, maybe above all, increasing financial benefits. Therefore, in an age of the commercialization of sport, it seems essential to find new formulas for promoting fair play [35].

In order to change the picture and to put potential interventions into practice, it is first necessary to check what the level of knowledge and the attitude of pupils (including those practicing sport competitively), students, and teachers of PE to these principles are, both in the context of obeying sports rules and the application of these principles to everyday life.

At the same time, the role of the principle of fair play is crucial from the perspective of the future, not only in terms of school PE or competitive sport, but also in the world beyond, as it is treated as a source of values in the modern educational process [35-37]. Also of importance is research on the relationship between PE and moral education [38,39], in which the principle of fair play actually constitutes the main support of one's sound development [40-45].

In the Polish education system, starting at the primary level and finishing with higher education, the ideals of Olympism based on the principle of fair play are currently put into practice, although this occurs to a minimal degree [46-48]. This is despite the fact that according to the general curriculum, as part of their social competence, a pupil finishing primary school should acquire the ability to adapt themselves to the principle of playing a 'clean game', and within that, respect their opponents, the rules of the game, and decisions of the referee. Moreover, they should possess the ability to behave properly in winning and losing situations. At the secondary school level, however, the pupil should be able identify the relationship between the values of Olympic ethics and life outside sport [49], which seems to be a minimal ethical requirement, considering the 12-year period of education involved. This is also where the knowledge of fair play, especially among children, is rather incidental and related with their own experiences and level of engagement in programs by extramural institutions promoting this principle, such as Olympic Committees or academic initiatives [47,50]. In order for the concept of fair play to serve the principle of moral perfection in sport well, participation in the process of sports education among the young should take place not only in an atmosphere of sports competitions but, above all, in the context of the personal and social qualities of PE teachers and coaches, as well as those cooperating with them on other terms (including families, school administration, peer groups, extracurricular sports, and recreation institutions). Although all of these are educational entities with similar responsibilities in the sound development of young people, PE teachers and coaches have been granted a leading role in promoting the values of fair play [51]. It seems that teachers and coaches, as well as students, should be aware of their social obligations to show and teach moral values to their students [52-54] through the educational process, where teacher-student relationships play a crucial role in students' holistic development, including their moral capabilities $[53,55,56]$.

From this perspective, gaining an understanding of the principles of fair play by pupils-as well as by PE students and PE teachers-as a group theoretically most be closely related with the Olympic philosophy and its key principle of fair play, which seems to be a task which is both interesting and worth researching [57]. Although diagnosing selected external factors (such as the influence of school education, religion, or media) influencing the development of moral competence in certain groups of respondents also seems important, one needs to keep in mind that there is not just one pattern of this influence that may be considered correct.

With the aim of analyzing the current situation, we conducted research concerning the level of understanding of the principle of fair play by pupils, PE students, and PE teachers. In addition, an analysis of factors which may influence the level of moral competence in each of the researched groups was carried out. 


\section{Materials and Methods}

This research study was conducted during the period 2017-2018. It included 827 secondary school pupils from the province of Wielkopolska (comprised of $45.4 \%$ boys and $54.6 \%$ girls aged $16.5 \pm 0.6$ years), 437 students studying for a degree in physical education at Poznan University of Physical Education (comprised of $49.4 \%$ male and $50.6 \%$ female, aged $21.5 \pm 1.85$ years, ranging from $56 \%$ to $76 \%$ of the entire student population for each year), and 130 teachers of physical education (comprised of $37.7 \%$ male and $62.3 \%$ female aged $44.1 \pm 9.5$ years, with an average length of professional career of $19.3 \pm 9.7$ years).

Due to the lack of a normal distribution in the analyzed groups, non-parametric statistical tools were employed. The chi-squared test was used in order to research the independence of the qualitative factors from the type of group being analyzed, namely those not practicing sport and those practicing sport at an amateur or professional level. The percentage distribution of indicators in the groups presented in Table 1 also contains chi-squared statistical values and probability. If $p<0.05$, the distribution of a given factor was dependent on the group, with it then becoming interesting in which categories a clear difference in the observed percentages would appear. Then, in order to describe differences related to angular velocities, the effect size values were calculated as the differences between the means divided by a pooled standard deviation. Using Cohen's criteria [58], an effect size $\geq 0.20$ and $\leq 0.50$ was considered small, $\geq 0.50$ and $<0.80$ was considered medium, and $\geq 0.80$ was considered large. To examine the relationships between variables, Spearman's correlation test was used with the value of correlation strength set at: $\leq 0.39$ weak, $0.40-0.59$ moderate, and $\geq 0.60$ strong. The existence of a statistical difference was defined at a level of $p<0.05$.

All statistical analyses were conducted with the aid of the version 13 Statistica program.

\subsection{Tools}

This research study was conducted by the diagnostic survey method with the use of a structured survey questionnaire previously prepared, tested, and assessed by competent judges.

One of the tools used to conduct the research was the three-level scale known as the Fair Play Moral Dimensions Concept Scale, previously developed by Parry [32] as three basic dimensions or levels of comprehension of fair play. The scale contains three statements referring to the levels (P1, P2, P3). The first level of the fair play principle (P1) is limited to the application of previously set/codified sporting rules during a sports competition. Another level of the fair play principle (P2) refers not only to the application of codified sporting rules during a competition, but also to the employment of a code of behavior resulting from the professional etiquette of those participating in competitive sport. The third level in the application of the principle of fair play (P3) defines all the desired behaviors of the sportspersons by which they will stand out, not only in their sporting life but in their everyday life, and the reverse. Those surveyed were asked to mark one of the levels in accordance with their understanding of the principle of fair play based on their own knowledge and previous experience. A conducted test-retest (following a two-week break) indicated a level of reliability of 0.78 . The internal consistency from Cronbach's Alpha coefficient value score was 0.66.

With the aim of validating the research tools applied, a procedure of explaining and assessing the psychometric properties of a translated text was employed. The aim of these actions was the possibility of comparing the results gained on an international plane. Cultural adaptation was also an element of validation, one which allowed for intercultural comparison and the practical application of the questionnaire. The co-validity of the tool adapted from the original version was aimed at five equally valid categories, namely: Superficial (uniform graphic appearance and questionnaire instructions), psychometric (correlation between the versions of the questionnaire), functionality (usefulness for identical aims), explanatory (content and degree of difficulty of vocabulary), and reconstruction (ways for measuring reliability and accuracy).

The research study also employed a tool proposed by the authors, namely the Factors of Moral Influence Scale [59], among which the following factors deemed to have a significance in the 
development of one's moral competence were distinguished, particularly: Religion, school, education, parents, Physical Education teacher, sport coach, peers, and media. This tool was constructed on the basis of the 5-point Likert scale of the following ranking, where 1 means 'not important' and 5 means 'very important', and concerned the question 'Who/what has the greatest influence on your moral competence?' A test-retest (on the same group after a two-week break) was conducted for these same factors, resulting in a range of $0.66-0.88$. The value scores, whose internal consistency was measured with Cronbach's Alpha coefficient, ranged from 0.60 to 0.67 for the pupils' sample, 0.62 to 0.071 in the PE students' sample, and 0.62 to 0.74 in the PE teachers' sample. In addition, information was gathered on the types and modes (amateur/professional) of sports practiced, as well as the periods of participation (in years) in situations in which such a declaration was made.

\subsection{Ethics}

All respondents were informed that their participation would be anonymous, along with the aim of the research and the manner in which the results gained would only be used for scientific purposes. It was additionally checked that the pupils and their legal guardians had granted their permission (confirmed in writing) concerning their voluntary participation in the research. Permission for carrying out the research was secured separately and granted by the directors of the institutions concerned. Furthermore, the respondents were informed of the possibility of withdrawing in cases where they felt the need not to answer certain questions included in the questionnaire. Before research was commenced, approval (no. 893/18) was received from the Bioethics Committee of the Karol Marcinkowski Medical University, Poznan for it to be conducted.

\section{Results}

Table 1 presents, in turn, the differences between the levels of comprehension of the phenomenon of fair play among pupils, students, and teachers with regard to their involvement in sports training (no training; amateur training; professional training). 
Table 1. Analysis of differences between the sexes in answers to questions concerning comprehension of the phenomenon of fair play among pupils, PE students, and PE teachers (in \%).

\begin{tabular}{|c|c|c|c|c|c|c|c|c|c|}
\hline \multirow[b]{2}{*}{ Subjects/Sex/No. } & \multicolumn{3}{|c|}{ Fair Play Level 1} & \multicolumn{3}{|c|}{ Fair Play Level 2} & \multicolumn{3}{|c|}{ Fair Play Level 3} \\
\hline & No Training & Amateur & Professional & No Training & Amateur & Professional & No Training & Amateur & Professional \\
\hline Pupils/M/375 & 2.1 & 9.3 & 10.1 & 1.9 & 26.9 & 17.6 & 2.4 & 18.9 & 10.7 \\
\hline Pupils/F/452 & 2 & 15.3 & 8.4 & 2 & 24.3 & 15.2 & 3.5 & 16.8 & 12.4 \\
\hline Chi-squared $\left(\chi^{2}\right)$ & $\chi^{2}=210.5$ & $\mathrm{df}=196$ & $p=0.23$ & $\chi^{2}=404.0$ & $\mathrm{df}=361$ & $p=0.06$ & $x^{2}=267.0$ & $\mathrm{df}=267$ & $p=0.50$ \\
\hline Students/M/216 & 0.5 & 6 & 7.4 & 1.9 & 28.2 & 16.7 & 1 & 19.4 & 19 \\
\hline Students/F/221 & 0.5 & 8.6 & 7.2 & 0 & 19.9 & 13.6 & 4.1 & 24.4 & 21.7 \\
\hline Chi-squared $\left(\chi^{2}\right)$ & $\chi^{2}=85.5$ & $\mathrm{df}=65$ & $p=0.04 *$ & $\chi^{2}=220.00$ & $\mathrm{df}=174$ & $p=0.01 *$ & $\chi^{2}=254.5$ & $\mathrm{df}=145$ & $p=0.02 *$ \\
\hline Teachers/M/50 & 2 & 4 & 8 & 0 & 20 & 10 & 2 & 18 & 19 \\
\hline Teachers/F/81 & 2.5 & 2.5 & 3.7 & 3.7 & 9.9 & 6.2 & 8.6 & 32.1 & 30.9 \\
\hline Chi-squared $\left(\chi^{2}\right)$ & $\chi^{2}=19.50$ & $\mathrm{df}=12$ & $p=0.80$ & $\chi^{2}=34.00$ & $\mathrm{df}=30$ & $p=0.30$ & $\chi^{2}=97.00$ & $\mathrm{df}=85$ & $p=0.21$ \\
\hline
\end{tabular}

Note: $\mathrm{M}-$ male, $\mathrm{F}-$ female. ${ }^{*}$ Statistical difference at the level of $p \leq 0.05$. 
An analysis of the research results in the pupils' group does not indicate clear differences in any of the levels of understanding of the principle of fair play in the categorized groups. At all levels, however, a large difference in the understanding of the principle of fair play may be noticed between adolescent boys and girls who do not practice sport and those who have taken up sport in an active manner.

At the same time, in the group of tested PE students, a clear difference is visible in the distribution of answers at each of the levels of one's understanding of the principle of fair play. At the first level, this comes to $p=0.04$; it is greatest at the second level, and comes to $p=0.01$. However, a slightly weaker difference between the sexes is displayed by the group situated in the highest field, particularly in the third level of one's understanding of the principle of fair play $(p=0.02)$. Here, one can also clearly see differences between male and female students in their comprehension of the principle of fair play according to the category of sporting activity practiced. Although in the PE student group, the second level was more frequently indicated by amateur sportsmen $(28.2 \%)$ and professional sportsmen $(16.7 \%)$ than by amateur sportswomen $(19.9 \%)$ and professional sportswomen (13.6\%), this was the reverse in the third level.

Among the PE teachers surveyed, similarly to the pupils, there was no clear statistical difference observed between the sexes in the comprehension of the principle of fair play among the categories concerning involvement in sporting activities (no training; amateur; professional). All that was noticed was that the female PE teachers' amateur training group more frequently identified the third level of comprehension of the principle of fair play (32.1\%) than their male colleagues.

A further step was analysis of the level of clear differences regarding particular external factors which were of significance for the three groups of respondents being researched (Table 2), divided along gender lines (male, female). 
Table 2. Most important factors influencing moral values as identified by respondents.

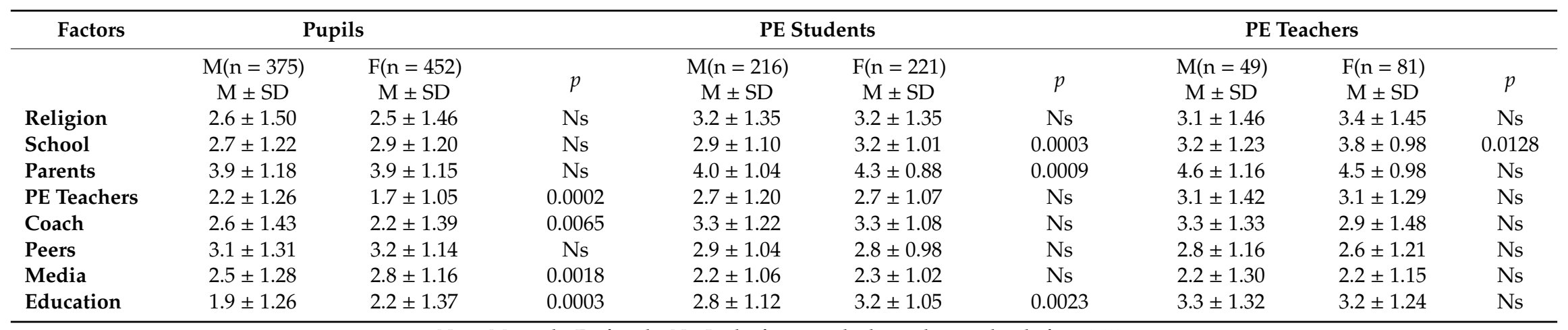

Note: $\mathrm{M}-$ male, F-female. Ns: Lack of statistical relationship at a level of $p \leq 0.05$. 
From the analysis of tests between boys and girls at the secondary school level, clear differences in terms of effect size criteria were noted in the following factors: PE teacher $(\mathrm{d}=0.43)$, education $(d=0.23)$, media influence $(d=0.25)$, and coach $(d=0.28)$, all as small. Here, one should notice that adolescent boys rated the influence of PE teachers and coaches on their moral development higher, while girls were influenced more by media and education. It is worth emphasizing that, among the remaining factors, parents constituted the highest-scored factor of influence on moral development for both boys $(\mathrm{M} \pm \mathrm{SD} 3.9 \pm 1.18)$ and girls $(\mathrm{M} \pm \mathrm{SD} 3.9 \pm 1.15)$.

Although male PE students also indicated the influence of parents on their moral development $t$ as the highest factor, female PE students scored this even higher $(\mathrm{d}=0.31)$. Although clear differences were also noticed regarding such factors as school $(\mathrm{d}=0.28)$ and education $(\mathrm{d}=0.37)$, both of which were scored higher by female PE students, the effect size was considered to be small.

Among PE teachers, the factor of school was clearly equated with the noticeably higher score awarded by female teachers $(\mathrm{M} \pm \mathrm{SD} 3.8 \pm 0.98)$ than by male teachers $(\mathrm{M} \pm \mathrm{SD} 3.2 \pm 1.23)$, which is seen as medium $(\mathrm{d}=0.54)$ according to Cohen's criteria. Similar to both of the above-described groups (pupils and students), it was observed that parents constituted the highest-scored factor of influence on moral development, with average values of $\mathrm{M} \pm \mathrm{SD} 4.6 \pm 1.16$ for male PE teachers and $\mathrm{M} \pm \mathrm{SD}$ $4.5 \pm 0.98$ among female PE teachers.

A correlation analysis indicated that there was no statistically significant relationship between fair play and individual factors from the Moral Influence Scale in secondary school pupils. In PE students, a positive but weak correlation was found in the case of the PE teacher factor (0.11), while among PE teachers, fair play was associated with the factors of the school (0.20) and parents (0.18).

\section{Discussion}

Although the principle of fair play constitutes the most important element of sports ethics, it does not mean it is easier to find more morally sound reasoning regarding those who are physically active. Despite originating in sport, it has been transferred to other areas of everyday life, at least being considered desirable from an educational and social perspective. The International Olympic Committee (IOC) as well as the World Health Organization (WHO) have shown that a significant decline in the level of physical activity has occurred in every corner of the world. In stressing the serious consequences for one's physical, emotional, and economic development, proposals for carrying out educational programs employing Olympic ideals are simultaneously presented [60], underpinning that the two spheres (physical and moral) need to be combined for the sustainability of the sound development of young people. Sustainable development in the case of PE can be seen as an interactive and interdisciplinary approach employing cognitive processing not just to understand, but to act accordingly, also in the future. For this, a certain emotional relationship with the values taught needs to be developed, based on personal experiences. Comprehension and extension in that development may help in the change from temporary to sustainable understanding and motivation [61] to incorporate fair play in the context of sport and beyond.

Evidence suggests that sporting activity may not only have an influence on one's physical development, but also moral development, both in positive and a negative way [7]. People progress through different developmental stages (physically and cognitively) in life, and various factors may influence their moral reasoning and disengagement, also beyond sport-related contexts. Therefore, when analyzing behaviors related with the effects of one's moral conduct both within or outside the context of sporting and physical activity, it is important to consider the environmental circumstances in which the process of upbringing took place and, which, in a certain sense, are determined by a socio-economic context [62]. An impoverished neighborhood is a strong predictor of moral disengagement at the age of 15 [63]; high dispositional moral disengagement will amplify unethical behavior in and beyond a sport setting [64]. Individuals high in moral disengagement also had lower levels of self-control in various daily situations [65]. Moreover, the type of sport may play a critical role in stimulating some forms of moral behaviors [66]. 
The biological conditions of certain behaviors are also not without significance, with psychological phenotypes such as aggression in sport constituting just one example [67]. This may also be associated with the developing brains of young adolescents-information processing capacity and working memory can be disturbed by a growing reward and control system, leading to risk-taking or unethical behaviors [68]. These limitations have not always been considered or challenged effectively, particularly in terms of sport education.

Educating one to practice a behavior of fair play as one of the most universal principles in sport and that goes beyond sport is, or at least should be, one of the most fundamental duties of modern education, not just through school PE classes, but throughout the schooling system. Its significance and influence on the moral development of its participants have been confirmed by research $[25,69]$. Positive changes in the attitudes of the young regarding sport and everyday life situations have been confirmed earlier by Kowalska [70]. In our own research, the highest percentage indicator across the groups referred to the second level of the understanding of fair play (concerning rules of the game and etiquette). However, a considerable percentage of adolescents, students, and teachers of both sexes, training as amateurs and professionals, declared their understanding of fair play as going beyond the sporting context (level 3). Similar results have been gained in research concerning young people in England [71], in which $71.4 \%$ of research participants acknowledged that they associated fair play with sport, while for $52.4 \%$, it was the conduct of every person in their daily life, regardless of whether they practiced sport or not. In the English study, however, for 31\%, there was no link between everyday life and sport. In addition, in our study, the percentages across the groups of those seeing fair play as something to be used just in the sporting context were much smaller and ranged between $2.5 \%$ and $15 \%$.

The results presented in this study also indicate that young people practicing physical activity had a decidedly higher level of understanding of the principle of fair play. Previous research on a different group of adolescents showed that young people need a sense of understanding and a suitable level of awareness in order to get involved in undertaking a life-long physical activity [72]. Unfortunately, recent research has indicated that the majority $(70 \%)$ of examined pre-service PE and sport students were classified on the basis of Lind's Moral Competence Test criteria [73] as presenting a low level of moral competence [74]. Findings from another study by Cummings et al. [52] indicate that it is a wider problem-moral reasoning levels of pre-service and in-service teachers are generally relatively low. It has been suggested that student-teachers' generally low levels of moral reasoning may be explained by the tendency for teacher education curricula to focus mainly on knowledge and their subsequent neglect of ethical issues [75]. In the case of PE students, the problem may be rooted in a still-present misconception in understanding the modern paradigm of $\mathrm{PE}$, namely in that a traditional physical sport-centered approach is still more present than a holistic approach, which would focus on enhancing social attitudes, moral development, and life-long learning skills in PE [74]. Such an educated level of awareness is also comprised of their conscious participation in sporting activity outside school, even though differences between the sexes frequently appear. In a study concerning teaching the values of sportsmanship in Spanish youth, Lequin and Oliden [76] found that the least important value was that of winning the game (for both genders), whereas the most important one differed for boys, who valued having fun, and girls, who considered playing fair as the most important factor. In turn, Sáenz Ibáñez et al. [77] indicated that schoolchildren playing competitive football displayed a higher level of understanding of fair play among those taking part in sports lessons than their non-physically active peers. Conversely, the culture of hegemonic performativity of school sport, which strongly emphasizes winning at all costs, may cause several problems. In another study on a Spanish population of competitive adolescent athletes, Palou et al. [11] found that the task climate was negatively related to the acceptance of gamesmanship and cheating, while the ego climate led to higher acceptance. In another study, Cruz et al. [26] observed that antisocial behavior in sport is related both to the type of sport practiced and the players' sex. Research studies have found that performance-oriented goals (i.e., goals focused on normative competences) were positively related with several moral 
variables, such as the legitimacy of committing injurious acts, approval of unsportsmanlike behavior, verbal/physical aggression, along with antisocial judgments and behavior [78,79]. In contrast, mastery goals (i.e., those focused on task-based or interpersonal competence) are linked to sportsmanship, less tolerance for aggression and cheating, respect for social conventions, rules, and officials, and pro-social judgments [79]. In a study by Hodge and Lonsdale [28], an autonomy-supportive coaching style was associated with prosocial behavior toward teammates, which was mediated by autonomous motivation. On the other hand, controlled motivation was linked with antisocial behavior (towards both teammates and opponents), with these relationships being mediated by moral disengagement. This is in accordance with the results of earlier studies which also examined the development of moral reasoning [6].

In research conducted by Stoll [80], it was noticed that participation in competitive sport may sometimes cause the disruption of the proper moral development of young people. Shields' and Bredemeier's [76] findings in a study on school youth indicate that cheating was approved by $14 \%$ of the teenagers concerned, 32\% thought it was fine to argue with officials, $22 \%$ accepted trash-talking as simply part of the game, $29 \%$ approved booing, $12 \%$ agreed that faking an injury is acceptable, and $41 \%$ accepted flashy, egotistical celebration.

Comparing our own results of PE students with professional volleyball and handball players who were students at the same time, one may observe that 'just' PE students are characterized by a higher level of understanding of fair play than those with professional sporting experience [81]. According to the latter, for a decided majority, fair play refers to conduct related exclusively with sporting activity. Few of them link this concept with everyday life. In turn, Shields and Bredemeier [82], in their comparative study on groups of students, did not observe a significant difference between professional players in college basketball games and those not practicing sport, although, generally speaking, there was a higher level of moral development and reasoning in female members of both groups over males. Lyons and Turner [44] found similar results when comparing levels of moral reasoning of intercollegiate athletes and students. Although there was no confirmation of a clear difference in the level of moral understanding between athletes and students, it was noticed that the moral development of women was clearly higher than that of men.

It seems that the most crucial moment for the moral development of young adolescents may be the moment of transition between the stages of secondary and tertiary education. In a study on a large cohort of students from the Millennial generation, Stephens [83] found that moral competency and autonomy in 18-19 year old adolescents was associated with parental support, specifically in sophomore students. Indeed, once young freshman students had separated from parents and began fostering autonomy, they needed some support from other sources such as university programs in helping them gain more independence from their parents.

Regarding the factors influencing moral development in our own research, secondary school pupils indicated that parents were the people who had the greatest influence on their value system. In another study in England [71], for 38\% of pupils, parents also constituted the basic source of knowledge on the subject of fair play, as well as in shaping their moral development. Of interest is the fact that in England, the person second in importance for the young people surveyed was their PE teacher (identified by $28.6 \%$ ), which was not the case in our own study.

At the teachers' level, an international comparative study revealed that for PE teachers and coaches from five countries (Greece, Romania, Bulgaria, Latvia, Italy), a basic source of values was the family [84]. In their view, $70 \%$ of pupils expect to be presented with models of behavior to be imitated. Comparable findings were observed in our study. Parents were rated the strongest source of influence on moral development by PE teachers of both sexes. A similar situation was noticed among PE students and school pupils.

Physical education pupils' moral behavior in school is also shaped by the principles and values that they share with their PE teacher and their classmates [85]. In relation to lessons in other subjects, although PE lessons offer more opportunities for pupil-teacher and pupil-pupil interactions, the 
implications of this go far beyond the sport gym—an ethical person in sport will restrain themselves from unethical behaviors in situations of daily life (no cheating in tests, no plagiarism, no violence, etc.). This is one of the main reasons that research studies have endorsed PE as the most satisfactory environment for conducting sociomoral education $[82,86,87]$. Morally developed and sound teachers seem to be more aware of the moral aspects of teaching and take more responsibility for them [52]. However, the moral development of pre-service and in-service teachers is still relatively low, again contradicting the moral nature of their profession [53].

At the same time, it is fundamental to introduce the principle of fair play with an Olympic education as early as possible in the educational process. Research concerning moral development shows that PE classes may have a positive influence on the development of young people in this area [69]. Moreover, there is a social imperative for PE to teach life skills essential to functioning in everyday life outside of the sport setting [88]. The best solution is to create situations during PE classes in which pupils must manage to solve problems and conflict situations, including solving moral dilemmas. Thanks to this, with the support of the teacher, pupils have the possibility of testing out various solutions, as well as observing the consequences of their own decisions, all of which influence their moral comprehension. PE classes taught properly with regard to fair play also facilitate the development of empathy among young people [89]. As various research studies conducted in secondary schools indicate, it is in schools in which an Olympic educational program has been implemented that pupils more willingly talk about Olympic values and present such attitudes in everyday situations [90,91]. This need has been confirmed by many researchers [25,37,47,70,92-98].

\section{Conclusions}

Based on the results of this study, we may say that although a substantial percentage of adolescents, PE students, and PE teachers have recognized the value of fair play beyond the field of sports and the rules of the game, it is still important to promote the idea of fair play via Olympic education in schools. This calls also for adjustments in curricula aimed at suitably preparing future teachers for the proper implementation of this ideal in the school environment, where the sensitization of young people to the concept of a 'clean game' during school studies will hopefully shape their moral outlooks and have an impact on their adult lives in a fundamental manner. Priority must be emphasized on the phenomenon of fair play in school sports, while having clear links to a context beyond the rules and setting of a sport gym [99]. Indeed, this should be a combined effort of all those involved-from parents, coaches, and sporting activists, through PE teachers and academic teachers, as otherwise, introduction of the idealistic values of fairness will be considered a utopia while our contemporary lifestyle will become the governing principle of sporting ethics. According to our findings, parents have been acknowledged as the main ally in this quest. The question remains as to why PE teachers or sport coaches have been given so little credit in this endeavor, a phenomenon which was visible across the examined groups and levels.

\section{Limitations}

Although one of the limitations of our study may be its cross-sectional design, its relatively large sample size may be viewed as a strength. We could have also engaged more in conducting qualitative analyses, adding a section of open questions in addition to the survey itself in order to give participants an opportunity to outline their own definition/understanding of the concept of fair play. While this would certainly have added some more impact to the findings, it creates an interesting path for further research. Such research should not only examine teachers, students, and pupils of all levels of education, but parents, sport coaches, organizers, officials, and referees, in order to obtain a broader picture of understanding the idea of fair play in society, as well as to potentially widen its social influence via specifically designed educational initiatives. 
Author Contributions: Conceptualization, M.B. (Małgorzata Bronikowska) and M.B. (Michał Bronikowski); Data curation, M.B. (Michał Bronikowski); Formal analysis, M.B. (Małgorzata Bronikowska) and M.B. (Michał Bronikowski); Investigation, M.B. (Małgorzata Bronikowska), A.K., B.P., J.K., and M.L. (Mateusz Ludwiczak); Methodology, M.B. (Małgorzata Bronikowska) and M.B. (Michał Bronikowski); Project administration, M.B. (Małgorzata Bronikowska); Resources, M.B. (Małgorzata Bronikowska), A.K., B.P., M.L. (Mateusz Ludwiczak), M.Ł. (Marlena Łopatka), S.W., J.E.K., and M.B. (Michał Bronikowski); Software, M.B. (Małgorzata Bronikowska); Supervision, M.B. (Michał Bronikowski); Validation, M.B. (Małgorzata Bronikowska) and A.K.; Visualization, M.B. (Małgorzata Bronikowska); writing一original draft preparation, M.B. (Małgorzata Bronikowska) and M.B. (Michał Bronikowski); writing-review and editing, M.B. (Małgorzata Bronikowska), A.K., B.P., J.K., M.L. (Mateusz Ludwiczak), M.Ł. (Marlena Łopatka), S.W., and J.E.K. All authors contributed to the development of the research and the writing of the article.

Funding: This research received no external funding.

Conflicts of Interest: The authors declare no conflict of interest.

\section{References}

1. Liponski, W. Brytyjska geneza sportu i koncepcji fair play. In Czysta Gra. Fair Play; Hadzelek, K., Rejf, M., Zdebska-Biziewska, H., Zukowski, R., Eds.; Fall: Warszawa, Poland, 2014; pp. 120-139.

2. Eyler, M.H. The Right Stuff. In Report of the 21st Session of the International Olympic Academy; International Olympic Academy: Athens, Greece, 1981; pp. 159-168.

3. Lenk, H. Towards a philosophical anthropology of the Olympic athlete. In Proceedings of the International Olympic Academy; International Olympic Academy: Lausanne, Switzerland, 1982; pp. 163-177.

4. Nissiotis, N. Olympism and today's reality. In Proceedings of the International Olympic Academy; International Olympic Academy: Olympia, Greece, 1984; pp. 57-74.

5. Liponski, W. Landmarks in British history and Culture. A Monograph of Selected Issues, 1st ed.; Wydawnictwo Naukowe UAM: Poznan, Poland, 2016.

6. Vargas-Mendoza, N.; Fregoso-Aguilar, T.; Madrigal-Santillan, E.; Morales-Gonzalez, A.; Morales-Gonzalez, J. Ethical concerns in sport: When the will to win exceed the spirit of sport. Behav. Sci. 2018, 8, 78. [CrossRef] [PubMed]

7. Cruz, J.; Ponseti, F.X.; Sampaio, M.; Gamito, J.M.; Marques, A.; Vinas, H.; Borrueco, M.; Carvalho, L.; Garcia-Mas, A. Effects of a Psychology-Based training programme on football grassroots coaches upon young player's sportspersonship and disposition to cheat. J. Sport Psychol. 2018, 27, 23-27.

8. Lance Armstrong's Confession. Available online: https://www.crimemuseum.org/crime-library/sportscrimes-2/lance-armstrongs-confession/ (accessed on 29 October 2019).

9. Bans Stand for Suspended Players. Available online: https://www.cricket.com.au/news/banned-trio-davidwarner-steve-smith-cameron-bancroft-sheffield-shield-aca/2018-11-20 (accessed on 29 October 2019).

10. Russia at Risk of Tokyo Olympics ban over 'inconsistent' Moscow Lab Data. Available online: https://www.theguardian.com/sport/2019/sep/23/russia-face-tokyo-olympics-ban-over-inconsistentmoscow-lab-data-athletics (accessed on 29 October 2019).

11. Palou, P.; Ponseti, F.X.; Cruz, J.; Vidal, J.; Cantallops, J.; Borras, P.A.; Garcia-Mas, A. Acceptance of gamesmanship and cheating in young competitive athletes in relation to the motivational climate generated by parents and coaches. Percept. Mot Skill 2013, 117, 1-14. [CrossRef] [PubMed]

12. Simon, R.L.; Torres, C.R.; Hager, P.F. Fair Play. The Ethics of Sport, 4th ed.; Taylor Francis, Routledge: New York, NY, USA, 2018.

13. Brundtland, G.H. Varldskommissionen for Miljo Och Utveckling [World Commission on Environment and Development: Our Common Future]; Translated and edited by B. Hagerhall, 408; Prisma: Stockholm, Sweden, 1988.

14. Davis, J. Young Children, Environmental Education, and the Future. Early Child. Educ. J. 1998, 26, 117-123. [CrossRef]

15. Davis, J. Revealing the Research 'Hole' of Early Childhood Education for Sustainability: A Preliminary Survey of the Literature. Environ. Educ. Res. 2009, 15, 227-241. [CrossRef]

16. Elliott, S.; Davis, J. Exploring the Resistance: An Australian Perspective on Educating for Sustainability in Early Childhood. Int. J. Early Child. 2009, 41, 65-77. [CrossRef]

17. Pramling, S.; Kaga, I.J. Introduction. In The Contribution of Early Childhood Education to a Sustainable Society; Samuelsson, I.P., Kaga, Y., Eds.; UNESCO: Paris, France, 2008; pp. 9-17. 
18. Lipiec, J. Filozofia Olimpizmu; PWS Sprint: Warszawa, Poland, 1999.

19. Krawczyk, Z. Kategorie Etyki Sportu. In Fair Play. Sport. Edukacja; Zukowska, Z., Ed.; Estrella: Warszawa, Poland, 1996; pp. 23-27.

20. Hassandra, M.; Goudas, M.; Hatzigeorgiadis, A.; Theodorakis, Y. A fair play intervention program in school Olympic education. Eur. J. Psychol. Educ. 2007, 22, 99-114. [CrossRef]

21. Knijnik, J.; Tavares, O. Educating Copacabana: A critical analysis of the "Second Half", an Olympic education program of Rio 2016. Educ. Rev. 2012, 64, 353-368. [CrossRef]

22. Naul, R. Olympic Education, 2nd ed.; Meyer Meyer Sport: Oxford, UK, 2008.

23. Bronikowski, M.; Bronikowska, M. Edukacja Olimpijska Dla Gimnazjum. Poradnik Dla Nauczycieli; Empi²: Poznan, Poland, 2010.

24. Naul, R.; Binder, D.; Rychtecky, A.; Culpan, I. (Eds.) Olympic Education. An International Review, 1st ed.; Routledge, Taylor Francis Group: London, UK; New York, NY, USA, 2017.

25. Gibbons, S.; Ebbeck, V.; Weiss, M. Fair Play for Kids: Effects on the Moral Development of Children in Physical Education. Res. Q. Exerc. Sport 1995, 66, 247-255. [CrossRef]

26. Cruz, J.; Ponseti, F.X.; Sampaio, M.; Garcia-Mas, A.; Nunez, A.; Ponseti, F.X.; Lara, M.; Gamito, J.M.; Marques, A.; Vinas., J.; et al. Effect of a Psychological training on football grassroot coaches upon young player's fairplay and disposition to cheat. J. Sport Psychol. 2017, 27, 24-30.

27. Garcia-Mas, A.; Rosado, A.; Serpa, S.; Marcolino, P.; Villalonga, T. Content Analysis of the Agents of Change "Disposition to Change" after attending the Psytool Program. J. Sport Psychol. 2017, 27, 31-36.

28. Hodge, K.; Lonsdale, C. Prosocial and antisocial behavior in sport: The role of coaching style, autonomous vs controlled motivation, and moral disengagement. J. Sport Exerc. Psychol. 2011, 33, 527-547. [CrossRef] [PubMed]

29. Shu, L.L.; Gino, F.; Bazerman, M.H. Dishonest deed, clear conscience: When cheating leads to moral disengagement and motivated forgetting. Pers. Soc. Psychol Bull. 2011, 37, 330-349. [CrossRef] [PubMed]

30. Mallia, L.; Chirica, A.; Galli, F.; Zelli, A.; Jaenes, J.C.; Garcia-Mas, A.; Lucidi, F. The role of achievement goals and moral disengagement in explaining moral attitudes and behaviours in sport. J. Sport Psychol. 2017, 27, 66-69.

31. Kowalska, J.; Kazmierczak, A. Zasada Fair Play Jako Wartosc Wychowawcza w Edukacji Szkolnej i w Przeciwdzialaniu Chuliganstwu Na Stadionach; Centr. Szkolenia Policji W Legionowie: Warszawa, Poland, 2010.

32. Parry, J. The Moral and Cultural Dimensions of Olympism and their Educational Application. In 100 Years as from the Foundation of the IOC: Commitments of the International Olympic Movement Towards the Modern Society of the 21st Century; Georgiadis, K., Ed.; International Olympic Academy: Olympia, Greece, 1995; pp. 181-195.

33. Culpan, I.; Wigmore, S. The Delivery of Olympism Education within a Physical Education Context Drawing on Critical Pedagogy. Int. J. Sport Health Sci. 2010, 8, 67-76. [CrossRef]

34. Culpan, I. Olympism, physical education and critical pedagogy. Eur. Phys. Educ. Rev. 2019, 5, 847-858. [CrossRef]

35. Young, K. Sport, Violence and Society, 2nd ed.; Routledge: London, UK, 2019.

36. Lis, J.; Olszanski, T. Czysta Gra. In Czysta Gra. Fair Play; Hadzelek, K., Rejf, M., Zdebska-Biziewska, H., Zukowski, R., Eds.; Fall: Warszawa, Poland, 2014; pp. 19-99.

37. Parry, J. Physical Education as Olympic education. Eur. Phys. Educ. Rev. 1998, 4, 153-167. [CrossRef]

38. Nowocien, J. Olimpizm i Fair Play Jako Zrodlo Wartosci w Nowoczesnym Procesie Edukacji. In Czysta Gra. Fair Play; Hadzelek, K., Rejf, M., Zdebska-Biziewska, H., Zukowski, R., Eds.; Fall: Warszawa, Poland, 2014; pp. 198-204.

39. Pennington, C.G. Moral Development and Sportsmanship in Interscholastic Sports and Physical Education. J. Phy. Educ. Rec. Dance 2017, 88, 36-42. [CrossRef]

40. Schwamberger, B.; Wahl-Alexander, Z.; Ressler, J. Ensuring Moral Development in Physical Education. Strategies 2017, 30, 33-37. [CrossRef]

41. Drewe, S.H. The logical connection between moral education and physical education. J. Curric. Stud. 2000, 32, 561-573. [CrossRef]

42. Mouratidou, K. Supporting Students' Moral Development through Physical Education. In Progress in Education; Nata, R.V., Ed.; Nova Science Publishers: New York, NY, USA, 2010; pp. 99-117.

43. Jacobs, F.; Knoppers, A.; Webb, L. Making sense of teaching social and moral skills in physical education. Phys. Educ. Sport Pedagog. 2013, 18,1-14. [CrossRef] 
44. Lyons, V.; Turner, B.A. Examining the influence of gender on athletes' levels of moral reasoning: A comparison of intercollegiate athletes and students. J. Iss. Intercolleg. Athl. 2015, 8, 28-49.

45. Karamavrou, S.; Mouratidou, K.; Evaggelinou, C.H.; Koidou, I.; Parisi, I. Moral Competence, Personality, and Demographic Characteristics: A Comparative Study. Ethics Prog. 2016, 7, 136-151. [CrossRef]

46. Vila, G.O.; Gonzalez, J.D.; Martin, J.F.; Fuentes-Guerra, J.G.; Jimenez Martin, P.J.; Jimenez Sanchez, C.; Robles, M.A.; Camacho-Minano, M.J. Moral development in sports at school age: Towards a fair play behaviours typology expressed in the White Card (Tarjeta Blanca) programme. Movem. Sport Sci.Sci. Mot. 2016, 91, 21-29. [CrossRef]

47. Glapa, A.; Bronikowski, M.; Laudanska-Krzeminska, I. Do Students Really Need Olympic Education at School? Stud. Sport Hum. 2016, 19, 30-36.

48. Bronikowski, M.; Bronikowska, M.; Glapa, A. Olympic education as patterns of sport institutions. In Olympic Education. An International Review. Part 3; Naul, R., Binder, D., Rychtecky, A., Culpan, I., Eds.; Routledge Taylor Francis Group: London, UK; New York, NY, USA, 2017; pp. 222-237.

49. Podstawa Programowa Ksztalcenia Ogolnego Dla Czteroletniego Liceum Ogolnoksztalcacego I Pięcioletniego Technikum z Przedmiotu Wychowanie Fizyczne. Available online: https:/podstawaprogramowa.pl/Liceumtechnikum/Wychowanie-fizyczne (accessed on 31 July 2019).

50. Zukowska, Z. Edukacja Olimpijska w Polsce i Wybranych Krajach. In Czysta Gra. Fair Play; Hadzelek, K., Rejf, M., Zdebska-Biziewska, H., Zukowski, R., Eds.; Fall: Warszawa, Poland, 2014; pp. 173-181.

51. Zukowska, Z.; Zukowski, R. Fair Play Jako Wartosc Edukacyjna w Sporcie a Sprawnosci Moralne Nauczyciela Wychowania Fizycznego i Trenera. In Fair Play W Sporcie i Olimpizmie. Szansa Czy Utopia; Zukowska, Z., Zukowski, R., Eds.; Estrella: Warszawa, Poland, 2010; pp. 60-71.

52. Cummings, R.; Dyas, L.; Maddux, C.D.; Kochman, A. Principled moral reasoning and behavior of pre-Service teacher education students. Am. Educ. Res. J. 2001, 38, 143-158. [CrossRef]

53. Cummings, R.; Harlow, S.; Maddux, C.D. Moral reasoning of in-Service and pre-Service teachers: A review of the research. J. Moral Educ. 2007, 36, 67-78. [CrossRef]

54. Sanger, M.; Osguthorpe, R. The moral vacuum in teachers' education research and practice. Yearb. Natl. Soc. Study Educ. 2013, 112, 41-60.

55. Sanger, M.; Osguthorpe, R. Teacher education, pre-Service teacher beliefs, and the moral work of teaching. Teach. Teach. Educ. 2011, 27, 569-578. [CrossRef]

56. Pantic, N.; Wubbels, T. Teachers' moral values and their interpersonal relationships with students and cultural competence. Teach. Teach. Educ. 2012, 28, 451-460. [CrossRef]

57. Parry, J. Ethical Aspects of the Olympic Idea. In Report on the I.O.A.'s Special Sessions and Seminars 1997; Eptalofos, S.A., Ed.; International Olympic Academy: Athens, Greece, 1998; pp. 233-248.

58. Cohen, J. Statistical Power Analysis for the Behavioral Sciences, 2nd ed.; Lawrence Erlbaum Associates: New York, NY, USA, 1988.

59. Bronikowska, M.; Korcz, A. The level of moral competences of pre-Service PE teachers-a reason to worry? Biomed Hum. Kinet. 2019, 11, 19-27. [CrossRef]

60. Nikolaus, I. The CIPC's International Network of Coubertin Schools: A Sustainable Model for an Olympic Education; International Pierre de Coubertin Committee Comite International Pierre de Coubertin (CIPC): Lausanne, Switzerland, 2015.

61. Dieleman, H.; Huisingh, D. Games by which to learn and teach about sustainable development: Exploring the relevance of games and experiential learning for sustainability. J. Clean. Prod. 2006, 14, 837-847. [CrossRef]

62. Bronikowski, M.; Bronikowska, M.; Laudanska-Krzeminska, I.; Glapa, A.; Morina, B. Sportsmanship attitudes in young adolescents from post-communist countries. Trends Sport Sci. 2014, 21, 161-168.

63. Hyde, L.W.; Shaw, D.S.; Moilanen, K.L. Developmental precursors of moral disengagement and the role of moral disengagement in the development of antisocial behavior. J. Abnorm Child Psychol. 2010, 38, 197-209. [CrossRef] [PubMed]

64. Moore, C. Moral disengagement. Curr. Opin. Psychol. 2015, 6, 199-204. [CrossRef]

65. Kouchaki, M.; Smith, I.H. The morning morality effect: The influence of time of day on unethical behavior. Psychol. Sci. 2014, 25, 95-102. [CrossRef]

66. Shields, D.L.; Bredemeier, B.L. Advances in Sport Morality Research. In Handbook of Sport Psychology, 3rd ed.; Tenenbaum, G., Eklund, R.C., Eds.; John Wiley Sons Inc.: Hoboken, NJ, USA, 2007; pp. 662-684. 
67. Gronek, P.; Wielinski, D.; Gronek, J. Genetic and non-Genetic determinants of aggression in combat sports. Open Life Sci. 2015, 10, 7-18. [CrossRef]

68. Steinberg, I. Risk taking in adolescence: New perspectives from brain and behavioral science. Curr. Dir. Psychol. Sci. 2007, 16, 55-59. [CrossRef]

69. Mouratidou, K.; Goutza, S.; Chatzopoulos, D. Physical education and moral development: An intervention programme to promote moral reasoning through physical education in high school students. Eur. Phys. Educ. Rev. 2007, 13, 41-56. [CrossRef]

70. Kowalska, J.E. The principle of fair play in the aspect of responsibility in the opinion of junior high schools students-Supporting sport clubs in Lodz. J. Educ. Health Sport 2018, 8, 836-848. [CrossRef]

71. Kowalska, J.E. Fair play i faul play w swiadomosci uczniow Greig City Academy w Londynie Awareness of fair play and foul play among the students of Greig City Academy in London. J. Educ. Health Sport 2015, 5, 457-473.

72. Bronikowski, M. Is sense of coherence needed to keep youth physically active? Med. Sport 2010, 63, 465-483.

73. Lind, G. Moral Competence Test (MCT) 2016b. Available online: https://www.uni-konstanz.de/ag-moral/ mut/mjt-engl.htm (accessed on 30 September 2019).

74. Bronikowska, M.; Korcz, A.; Krzysztoszek, J.; Bronikowski, M. How Years of Sport Training Influence the Level of Moral Competences of Physical Education and Sport Students. Biomed Res. Int. 2019, 2019, 4313451. [CrossRef] [PubMed]

75. Lampe, J.R. Teacher education students' moral development and ethical reasoning processes. Int. J. Educol. 1994, 8, 1-25.

76. Lequin, L.M.I.; Oliden, P.E. Perception of fair play in children and youth sport. Rev. Psicol. Deporte 2012, 21, 253-259.

77. Saenz Ibanez, A.; Gimeno Marco, F.; Gutierrez Pablo, H.; Lacambra Correas, D. Evaluation of the Sportsmanship-Aggression Continuum in Youth Football. Rev. Psicol. Deporte 2019, 28, 33-40.

78. Kavussanu, M.; Roberts, G. Moral functioning in sport: An achievement goal perspective. J. Sport Exerc. Psy. 2001, 23, 37-54. [CrossRef]

79. Sage, L.; Kavussanu, M.; Duda, J. Goal orientations and moral identity as predictors of prosocial and antisocial functioning in male association football players. J. Sports Sci. 2006, 24, 455-466. [CrossRef] [PubMed]

80. Stoll, S.K. The effects of athletic competition on character development in college Student-Athletes. J. Coll. Character 2012, 13, 14. [CrossRef]

81. Bodasinska, A.; Bodasinski, S.; Piech, K. Widowisko Sportowe w Kategoriach Wartosci Fair Play w Ocenie Zawodniczek i Zawodnikow Zespolowych Gier Sportowych. In Pedagogiczny Wymiar Kultury Fizycznej i Zdrowotnej w Zyciu Wspolczesnego Czlowieka; Kazmierczak, A., Kowalska, J.E., Maszorek-Szymala, A., Makarczuk, A., Eds.; Wydawnictwo Uniwersytetu Lodzkiego: Lodz, Poland, 2016; pp. 63-88. [CrossRef]

82. Shields, D.L.; Bredemeier, B.J. Character Development and Physical Activity; Human Kinetics Publishers: Champaign, IL, USA, 1995.

83. Stephens, D.G. A Correlational Study on Parental Attachment and Moral Judgment Competence of Millennial Generation College Students. Available online: http://digitalcommons.unl.edu/cehsdiss/32/ (accessed on 27 August 2019).

84. Fair Play and Happiness Through Sports. Available online: https://www.fairhap-project.eu/wp-content/ uploads/2017/09/A2_Attitudes-regarding-social-and-moral-values-of-sportp.e.-teachers-and-coaches2nd-Report.pdf (accessed on 27 August 2019).

85. Power, F.C.; Higgins, A.; Kohlberg, L. Lawrence Kohlberg's Approach to Moral Education; Columbia University Press: New York, NY, USA, 1989.

86. Miller, S.; Bredemeier, B.; Shields, D. Sociomoral Education Through Physical Education with At-Risk Children. Quest 1997, 49, 114-129. [CrossRef]

87. Drewe, S. The value of knowledge/rationality or the knowledge/rationality of values: Implications for education. Stud. Philo. Educ. 2001, 20, 235-244. [CrossRef]

88. Rus, C.M.; Radu, L.E. The implications of physical education and sport in the moral education of high school students. Rev. Cercet. Interv. So. 2014, 45, 45-55.

89. Sezen-Balcikanli, G. Fair play and empathy: A research study with student teachers. J. USA China Public Adm. $2009,6,79-84$. 
90. Zilionyte, V.; Poteliuniene, S. Olimpinio ugdymo programos realizavima Lietuvos bendrojo lavinimosi mokyklose skatinantys ir apsunkinantys veiksniai. Sporto Mokslas 2012, 67, 45-51.

91. Sukys, S.; Majauskiene, D. The attitude towards Olympism values of pupils in schools implementing and not implementing integrated Olympic education. Balt. J. Sport Health Sci. 2013, 91, 46-52. [CrossRef]

92. Bronikowski, M. Etyczne aspekty wychowawczego programu edukacji olimpijskiej. Wnioski z badan. Rocz. Nauk. AWF Gdan. 2001, 10, 141-173.

93. Vidoni, C.; Ward, P.H. Effects of Fair Play Instruction on student social skills during a middle school Sport Education unit. Phys. Educ. Sport Pedagog. 2009, 14, 285-310. [CrossRef]

94. Georgiadis, K. The Implementation of Olympic Education Programs at World Level. Procedia Soc. Behav. Sci. 2010, 2, 6711-6718. [CrossRef]

95. Chatziefstathiou, D. Olympic Education and Beyond: Olympism and values legacies from the Olympic and Paralympic Games. Educ. Rev. 2012, 64, 385-400. [CrossRef]

96. Sukys, S.; Majauskien, D. Effects of an Integrated Olympic Education Program on Adolescent Athletes' Values and Sport Behavior. Soc. Behav. Personal. 2014, 42, 811-821. [CrossRef]

97. Kohe, G.Z.; Bowen-Jones, W. Rhetoric and realities of London 2012 Olympic education and participation 'legacies': Voices from the core and periphery. Sport Educ. Soc. 2016, 21, 1213-1229. [CrossRef]

98. Okada, Y.; Nemoto, S. Trends in Research about "Olympic Education" in the English Literature: A review of the Decade 2008-2017. Jpn. J. Sport Educ. Stud. 2019, 38, 21-33. [CrossRef]

99. Zorba, E. Fair Play Behavior in Futsal: Study in High School Students. Univers. J. Educ. Res. 2018, 6, 1449-1453. [CrossRef]

(C) 2019 by the authors. Licensee MDPI, Basel, Switzerland. This article is an open access article distributed under the terms and conditions of the Creative Commons Attribution (CC BY) license (http://creativecommons.org/licenses/by/4.0/). 